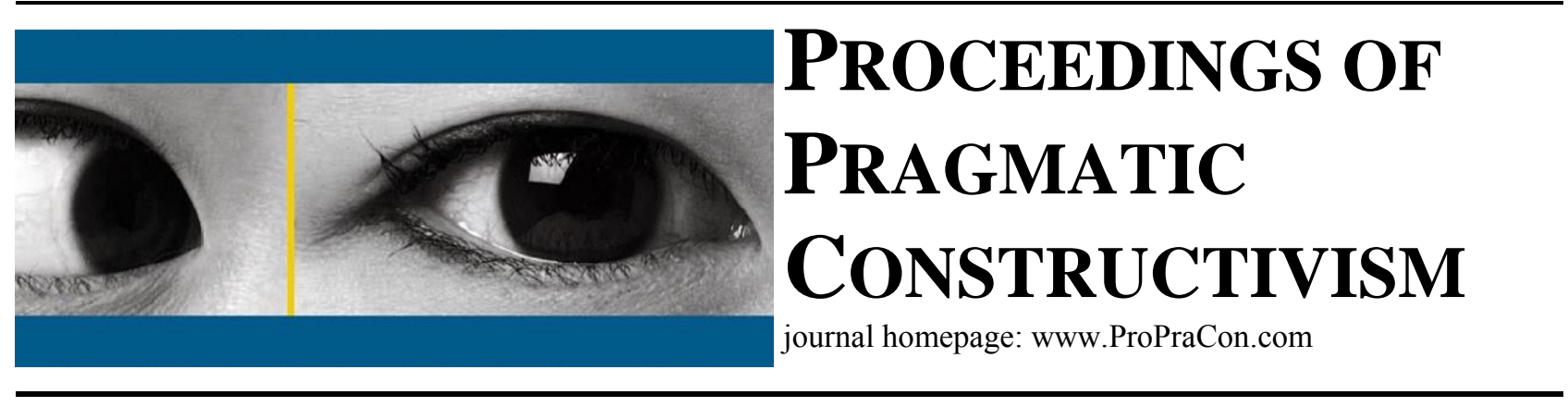

\title{
How to start a new research project: a guideline for thesis writers
}

\author{
Rainer Lueg
}

Associate Professor of Management Accounting and Control

Aarhus University; School of Business and Social Sciences; Department of Economics and Business

Fuglesangs Allé 4, 8210 Aarhus V, Denmark; rlueg@asb.dk

\begin{abstract}
This paper suggests how to start a new research project. As such, it can be used as a guideline by less experienced thesis writers that are currently finishing their studies on the undergraduate, graduate, or postgraduate level. The basis for the suggestions are publications that link topically to research projects I have started during my theses, revised with coauthors, and published in journals, books, conference proceedings, or edited volumes.
\end{abstract}

Keywords: guideline, thesis, research project, didactics.

\section{How to start a new research project: a guideline for thesis writers}

\author{
Rainer Lueg \\ Aarhus University \\ rlueg@asb.dk
}




\section{This presentation builds upon some of my own experience with past research projects}

Source of suggestions

Burkert, M., \& Lueg, R. 2013. Differences in the sophistication of Value-based Management - The role of top executives. Management Accounting Research, 24(1): 3-22.

Lueg, R. 2008. IFRS für den Mittelstand: Experteninterviews, Beispiele und internationaler Rechtsvergleich. München: AVM.

Lueg, R. 2008. Value-based Management: Empirical Evidence on its Determinants and Performance Effects. Vallendar: WHU Otto Beisheim School of Management.

Lueg, R. 2009. Führt der Einsatz externer Berater zur Überimplementierung innovativer Steuerungsinstrumente? Zeitschrift der Unternehmensberatung, 4(6): 249-253.

Lueg, R. 2010. Shareholder Value und Value Based Management - Wie steuern die HDAX-Konzerne? Zeitschrift für Controlling, 22(6): 337-344.

Lueg, R. 2010. Value-based Management - Antecedents and performance effects. In K. Pantz (Ed.), Summa Cum Laude 2008: Wirtschaftswissenschaften: 284-285. Darmstadt: Roter Fleck Verlag

Lueg, R., \& Borisov, B. G. 2012. Are you sure about what you mean by 'uncertainty'? The actor's perspective vs. the institutional perspective. Proceedings of Pragmatic Constructivism, forthcoming.

Lueg, R., \& Borisov, B. G. 2014. Archival or perceived measures of environmental uncertainty? Conceptualization and new empirical evidence. European Management Journal: forthcoming.

Lueg, R., \& Schäffer, U. 2010. Assessing empirical research on Value-based Management: guidelines for improved hypothesis testing. Journal für Betriebswirtschaft, 60(1): 1-47.

\section{An example:}

How do financial institutions ensure effective control?

Current contemplations on my next project (1/2)

\section{FRAMEWORK ISSUES}

\begin{tabular}{|c|c|}
\hline Question & $\begin{array}{l}\text { - How do financial institutions ensure effective control? } \\
\text { - Differences to manufacturing / services? } \\
\text { - What differentiates control by IA? }\end{array}$ \\
\hline $\begin{array}{l}\text { Motivation } \\
\text { (puzzle) }\end{array}$ & $\begin{array}{l}\text { - Little knowledge on control in financial institutions } \\
\text { - Bank failures despite control from various functions } \\
\text { - Current trend: IA as sub-function of risk management }\end{array}$ \\
\hline Roots & $\begin{array}{l}\text { - Power and independence of other actors in the organization } \\
\text { - Lack of internal governance and external regulation (tightness, enforcement) } \\
\text { - Skills, knowledge, manpower of IA too low }\end{array}$ \\
\hline $\begin{array}{l}\text { Persistent } \\
\text { anomalies }\end{array}$ & $\begin{array}{l}\text { - Are issues in IA the root or a byproduct? } \\
\text { - How can IA be in the role of a whistle blower? }\end{array}$ \\
\hline $\begin{array}{l}\text { New } \\
\text { theories }\end{array}$ & - tbd \\
\hline
\end{tabular}


What data should be accessed to gain a comprehensive understanding of the problem and to be versatile for publications?

Current contemplations on my next project $(2 / 2)$

Interviews (key informant) Interviews (expert)

Archival data (internal/external)

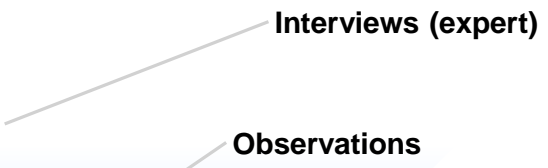

\section{Annual reports TOOLS Survey}

CONTEXTUAL FIT (Selection, systems, interaction)

\section{ANTECEDENTS}

- Literature review

- Factors

- Economic

- Social

- Psychological
MANAGEMENT

PRACTICE (IA)

- Role, outsourcing

- Design, process

- Use, dialogue, reporting

- Cross-sectional vs. longitudinal
PERFORMANCE \&

ASSESSMENT

- Actors

- Functions

- Institutions

- Regimes

Larger projects can address the research questions with different data sets and different methodologies

Steps in developing a larger project

1. Start with expert interviews and literature review to understand the industry / function

2. Case study to answer first propositions and to derive hypotheses

3. Take field study on the side if possible ( 1 company questionnaire across actors / departments)

4. Large scale study involving audited or archival data 


\section{Basis of recommendations / References for further reading}

Arbnor, I., \& Bjerke, B. 2008. Methodology for Creating Business Knowledge. Thousand Oaks, CA: Sage.

Booth, W. C., Colmb, G. G., \& Williams, J. M. 2008. The Craft of Research (3rd ed.). Chicago, IL: University of Chicago Press.

Burkert, M., \& Lueg, R. 2013. Differences in the sophistication of Value-based Management - The role of top executives. Management Accounting Research, 24(1): 3-22.

Campbell, C. A. 2010. The One-Page Project Manager: Communicate and Manage any Project with a Single Sheet of Paper. New York, NY: Wiley \& Sons.

Hoque, Z. 2006. Methodological Issues in Accounting Research: Theories and Methods. London: Spiramus Press.

Lueg, R. 2008. IFRS für den Mittelstand: Experteninterviews, Beispiele und internationaler Rechtsvergleich. München: AVM.

Lueg, R. 2008. Value-based Management: Empirical Evidence on its Determinants and Performance Effects. Vallendar: WHU Otto Beisheim School of Management.

Lueg, R. 2009. Führt der Einsatz externer Berater zur Überimplementierung innovativer Steuerungsinstrumente? Zeitschrift der Unternehmensberatung, 4(6): 249-253.

Lueg, R. 2010. Shareholder Value und Value Based Management - Wie steuern die HDAX-Konzerne? Zeitschrift für Controlling, 22(6): 337-344.

Lueg, R. 2010. Value-based Management - Antecedents and performance effects. In K. Pantz (Ed.), Summa Cum Laude 2008: Wirtschaftswissenschaften: 284-285. Darmstadt: Roter Fleck Verlag

Lueg, R., \& Borisov, B. G. 2012. Are you sure about what you mean by 'uncertainty'? The actor's perspective vs. the institutional perspective. Proceedings of Pragmatic Constructivism, forthcoming.

Lueg, R., \& Borisov, B. G. 2014. Archival or perceived measures of environmental uncertainty? Conceptualization and new empirical evidence. European Management Journal: forthcoming.

Lueg, R., \& Schäffer, U. 2010. Assessing empirical research on Value-based Management: guidelines for improved hypothesis testing. Journal für Betriebswirtschaft, 60(1): 1-47.

Ryan, B., Scapens, R. W., \& Theobald, M. 2002. Research Methods and Methodology in Finance and Accounting (2nd ed.). Stamford, CT: Cengage Learning.

Strunk, W. J., \& White, E. B. 1999. The Elements of Style (4th ed.). New York: Longman.

Yin, R. K. 2009. Case Study Research: Design and Methods (4th ed.). Thousand Oaks, CA: Sage. 